Dariusz Jarosz

Instytut Historii Polskiej Akademii Nauk, Warszawa, Polska

darjarosz@wp.pl

ORCID 0000-0002-7882-8532

http://doi.org/10.33077/zbkh.2018.12.jarosz

\title{
Reinterpretacja tradycji Drugiej Rzeczypospolitej jako element ideologizacji polityki wobec książki w Polsce lat 1944-1956
}

\author{
Abstract
}

\section{Reinterpretation of the Second Polish Republic tradition as an element of the ideologization of politics towards books in Poland in the period 1944-1956}

\begin{abstract}
Negative assessments of the pre-war book situation were used as justification for some of the changes in this field made in 1945-1956. The reference to a deliberately distorted picture of the book's situation in the Second Polish Republic intensified during the most revolutionary changes in this respect, the essence of which was bureaucratic planning, etatization and control of the processes of its issuing, production, sale and distribution. The problem that requires further research is the answer to the question of how the arguments used in ,blackening” the image of book affairs in the Second Polish Republic could be convincing for those to whom they were directed.
\end{abstract}

Key words: Second Polish Republic - stalinism in Poland - politics towards books bibliology - book-keeping.

Słowa kluczowe: Druga Rzeczpospolita - stalinizm w Polsce - polityka wobec książki bibliologia - księgarstwo.

Reinterpretacja tradycji II Rzeczpospolitej w zakresie polityki (a raczej polityk) wobec książki, jaka następowała w Polsce Ludowej przechodziła złożone transformacje, z których każda winna być interpretowania w kontekście konkretnego czasu i miejsca. Można oczywiście stwierdzić, że ta polityka była kontrolowana w latach 1944-1989 przez komunistów i cały system produkcji książek, ich dystrybucji i upowszechniania był podporządkowany celom partii rządzącej. Problem w tym, że takie twierdzenie jest na tyle oczywiste, że nadaje 
się na polityczny i ideologiczny slogan, który niewiele wyjaśnia ze skomplikowanych i dynamicznie zmieniających się relacji między sprawami książki a władzą. Jest wszak istotna, wręcz fundamentalna różnica między prowadzoną na przełomie lat 40. i 50. tzw. melioracją księgozbiorów przy zastosowaniu politycznych kryteriów uderzających nie tylko we ,wrogie” książki przedwojenne, ale również broszury autorstwa właśnie odsuniętych od władzy tzw. prawicowo-nacjonalistycznych „odchyleńców”, z Władysławem Gomułką na czele, a dyskusjami w kręgach najwyższych czynników partyjnych w końcu lat 80. nad tym, jak „,najmniej szkodliwie” dopuścić do publikacji dotychczas traktowanej jako wroga literatury powojennej emigracji.

W tym tekście chciałbym spróbować zastanowić się nad dwoma podstawowymi kwestiami:

1. jaki był kierunek reinterpretacji doświadczeń II RP w zakresie polityki wobec książki w latach 1944/45-1956 i czy ulegał on zmianom w tym okresie;

2. na ile owa reinterpretacja była wykorzystywana jako uzasadnienie dokonywania najważniejszych zmian w bibliotekarstwie, bibliologii, czytelnictwie, księgarstwie i polityce wydawniczej.

W niniejszym artykule nie zajmuję się szczegółowo samymi przemianami polityki wobec książki, które już po wielekroć były analizowane. Wzmiankuję o nich wtedy, gdy kreślę ogólny kontekst przeprowadzanych zmian oraz gdy towarzyszyła im argumentacja odwołująca się do odpowiednio reinterpretowanych doświadczeń przedwojennych. Interesuje mnie przede wszystkim analiza dyskursu na temat spraw książki.

Wybór cezur nie był przypadkowy. Chodziło o konfrontację dwóch okresów w historii Polski Ludowej (1944/45-1948 i 1949-1956), które zwykle są postrzegane jako istotnie różniące się.

W pierwszym z nich gomułkowskie kierownictwo partii próbowało realizować elementy „polskiej drogi do socjalizmu”, co w kulturze zwykle jest symbolizowane przez borejszowskie hasło „łagodnej rewolucji”. Okres od 1949 r. to początek (według wielu historyków - apogeum) stalinizmu, kiedy nastąpiła intensywna sowietyzacja wszystkich dziedzin życia politycznego, społecznego i kulturalnego. W tworzeniu ,nowego człowieka” socjalizmu, co było celem wysiłków wychowawczych, istotną rolę miała odegrać odpowiednio dobrana lektura.

W przypadku polityki wobec książki ta wewnętrzna cezura nie jest ostra. Dla obiegu książek i czytelnictwa kluczowe są lata 1948-1949. W marcu 1948 r. Rada Państwa przyjęła uchwałę o planowej akcji upowszechniania czytelnictwa. Po wskazaniu na niedomagania (brak ogólnego planu wydawniczego, wysoka cena książki, niskie nakłady, niedostateczny „dopływ książki do szerokich mas”) postulowano podjęcie „szerokiej akcji” na tych polach. 
Jej wytyczne przewidywały: opracowanie planu wydawniczego oraz stworzenie warunków dla jego wykonania; zapewnienie masowemu czytelnikowi dostępu do książki zarówno w formie wypożyczenia, jak możliwości nabycia przez: przełamanie drożyzny książki, zorganizowanie masowej akcji jej propagowania, przystąpienie do realizacji wytycznych ustawy bibliotecznej w zakresie stworzenia sieci bibliotecznej, wzmocnienie i rozwijanie „sieci rozprowadzającej, która by zapewniła możność nabycia taniej i dobrej książki" oraz zorganizowanie akcji poradnictwa w jej wyborze. W tym celu postanowiono powołać nową instytucję, która wkrótce (7 V 1948 r.) przyjęła nazwę Komitet Upowszechniania Książki ${ }^{1}$. W 1949 r. przygotowaniem planu produkcji książek zajęła się powołana przy Prezydium Rządu Centralna Komisja Wydawnicza. To ona sporządziła taki plan na rok $1950^{2}$. W przypadku polityki wobec wydawców zwykle jako cezurę wewnętrzną traktuje się rok 1949 (poddanie prywatnych wydawnictw mechanizmowi koncesjonowania), a wobec księgarstwa - 1950 (zarządzenie prezesa Rady Ministrów z 15 I 1950 r. o utworzeniu Centrali Obrotu Księgarskiego „Dom Książki”, co doprowadziło do likwidacji księgarstwa prywatnego). Wcześniej ,,uporano się" z księgarstwem autentycznie spółdzielczym³ ${ }^{3}$.

Przeprowadzanie tych generalnych, jak też bardziej szczegółowych zmian w polityce wobec książki odbywało się w dużej części przy użyciu argumentacji odnoszącej się do międzywojnia. Aby ją odtworzyć i przeanalizować konieczne okazało się dokonanie skrupulatnej kwerendy zarówno publicystyki na łamach prasy branżowej, jak też przechowywanych w archiwach tekstów referatów, programów szkoleń czy też protokołów dyskusji różnych gremiów na te tematy. Mało owocna okazała się lektura publikowanych opracowań i wspomnień, gdzie ta problematyka pojawia się incydentalnie.

\section{Czytelnicy i czytelnictwo}

Argumentem często powtarzanym w powojennych dyskusjach o sprawach książki w Drugiej Rzeczpospolitej był skandalicznie zły poziom czytelnictwa, co skutkowało „kompromitująco” niskimi nakładami książek. Próbując

\footnotetext{
Planowa akcja upowszechniania czytelnictwa, „Przegląd Księgarski” 1948, nr 5, s. 70; Uchwała Rady Państwa w sprawie upowszechnienia ksiązki i czytelnictwa w Polsce, „Bibliotekarz" 1948, nr 3, s. 33.

2 S. Kondek, Władza i wydawcy. Polityczne uwarunkowania produkcji ksiażek w Polsce w latach 1944-1949, Warszawa 1993, s. 192.

3 Na ten temat: zob. M. Tobera, Księgarstwo spótdzielcze i prywatne w okresie trójsektorowości polskiego rynku książki (1945-1950), „Przegląd Biblioteczny” 2014, nr 3, s. 329-363; tenże, Wtadza i księgarze prywatni (1945-1950), [w:] Nie po myśli władzy. Studia nad cenzura i zakresem wolności stowa na ziemiach polskich od wieku XIX do czasów wspótczesnych, Toruń 2012, s. 99128.
} 
w 1947 r. wskazać na najważniejsze przyczyny tego stanu, Stanisław Malawski pisał o niskim poziomie oświaty powszechnej, spowodowanym nie tylko półtorawiekową niewolą polityczną, ale również ,niewolą ekonomiczną warstw ludowych” i „tradycjami elitaryzmu szlacheckiego”. Twierdził także, że:

Jeśli bowiem z jednej strony różne ciemne siły społeczne, rzekomo narodowe, kładły tamy rozwojowi powszechnej oświaty, to z drugiej strony ciemny i egoistyczny aparat handlowy nie docierał $z$ artykułami dóbr kulturalnych w głąb mas ludowych $i$ tym samym nie stwarzał okazji do ich nabywania. Od tego uzależniona była polityka produkcji tych dóbr, a na odcinku książki - polityka wydawnicza.

To upośledzenie w zakresie czytelnictwa dotyczyło szczególnie wsi, do której „przeciekanie książki” przed 1939 r. „było wielce przypadkowe i niestałe”.

Przy okazji kampanii propagandowej w związku z wydaniem ustawy o likwidacji analfabetyzmu z 7 IV 1949 r. pisano niezwykle krytycznie o stanie szkolnictwa w przedwojennej Polsce:

Dla kapitalistów było w Polsce nie tylko za dużo ludzi ze średnim wykształceniem, za dużo także było ludzi umiejących czytać i pisać. [...] Co dziesiąte dziecko pozbawione było możliwości osiągnięcia tego minimum wykształcenia, jakie daje szkoła powszechna. Ta ogromna ilość dzieci, pozbawionych przez ustrój kapitalistyczny szkół, to nasi dzisiejsi analfabeci. Kapitalizm „,łławił ich możliwości twórcze. Rosła armia analfabetów i półanalfabetów. Tragicznym finałem szkodliwej dla kraju polityki sanacyjnej była klęska wrześniowa i 5-letnia niewola, powodująca nowy analfabetyzm w Polsce" . Skala analfabetyzmu jako jeden z wielu niechlubnych ,rekordów europejskich" przedwojennej Polski była ,żelaznym” tematem stalinowskiej publicystyki ${ }^{6}$. Przedstawiano w niej sylwetki analfabetów, którzy w dwudziestoleciu międzywojennym byli zmuszeni ciężko pracować i nie mieli szans na naukę pisania i czytania. Po wojnie, po ukończeniu odpowiednich kursów i nabyciu tych umiejętności mieli stać się ,pełnowartościowymi obywatelami, walczącymi o dobrobyt ludzi pracy"’.

W opozycji do tych opinii w ciepłych słowach wskazywano na pierwsze efekty ustawy z kwietnia 1949 r., cytowano entuzjastyczne wypowiedzi byłych analfabetów, którzy dzięki nabyciu możliwości czytania i pisania mogli realizować swoje plany życiowe ${ }^{8}$.

Co ciekawe, w okresie tuż powojennym można znaleźć porównania

4 S. Malawski, Książki na wieś, „Biuletyn Księgarstwa Spółdzielczego” 1947, nr 9, s. 120.

5 Źródła analfabetyzmu w Polsce $i$ walka państwa ludowego z tym zaniedbaniem kulturalnym, [Warszawa 1949], s. 1-2.

6 Zob. np. Z tego «rekordu» trzeba zrezygnować, „Kurier Szczeciński” 1951, nr 16.

7 Wczoraj analfabeci - dziś petnowartościowi obywatele Polski Ludowej, „Słowo Ludu” 1951, nr 65.

8 Tamże, s. 5-7. 
czytelników przedwojennych z powojennymi, które wypadały na korzyść tych pierwszych. Jan Augustyniak twierdził, że byli oni bardziej obyci z zasadami użytkowania biblioteki, wykazywali ,żywy i głęboki stosunek do książki”. W 1945 r. autor pisał, że:

Teraz przyszedł czytelnik - dziki. Nie zna adresu biblioteki i zgłasza pretensje, dlaczego o tak poważnej bibliotece nie pisze się w prasie co dzień? Następnie o przepisach bibliotecznych nie ma pojęcia [...]. Szczególny opór wywołuje np. zarządzenie o zdjęciu płaszcza w szatni. [...] Stosunek do książki jako własności społecznej jest niepokojący. Wprawdzie i dawniej byli Wandalowie biblioteczni, lecz dzisiaj ta przestępczość spotęgowała się wielokrotnie?.

Wydaje się, że ten krytyczny ton szybko zanika ustępując miejsca zachwytowi nad nowym, masowym czytelnikiem.

\section{Biblioteki, bibliotekarze, bibliologia}

Uchwalenie Dekretu o bibliotekach i opiece nad zbiorami bibliotecznymi z 17 IV 1946 r. było interpretowane jako spełnienie oczekiwań polskiego bibliotekarstwa, których nie mogła zaspokoić przedwojenna Polska. W „Przeglądzie Bibliotecznym" pisano:

Ileż to lat bibliotekarstwo polskie czekało na ten moment! Ile lat w Polsce przedwrześniowej trwały bezowocne zabiegi o ustawę biblioteczną, o organizację sieci bibliotek, o pomoc Państwa wykonywaniu ich zadań. Sprawy te zostały rozwiązane dopiero w Polsce Ludowej ${ }^{10}$.

W zachowanym w zbiorach archiwalnych Ministerstwa Oświaty uzasadnieniu do projektowanej pierwotnie ustawy (a nie dekretu) o bibliotekach i opiece nad zbiorami bibliotecznymi stwierdzano, że sprawy sieci bibliotek w Polsce „nie zostały dotychczas należycie załatwione”. Po odzyskaniu niepodległości w 1918 r. „nie wyszliśmy poza projekty”, „brak było [...] podstaw prawnych, organizacyjnych a przede wszystkim finansowych" oraz: „W 1936 r. 4 mil. tomów na ok. 9 mil. mieszkańców miast, a zaledwie 1 mil. tomów ok. 24 mil. ludności wiejskiej. Cyfry te mają swoją wymowę"11.

Odnosząc się do stanu książnic w Drugiej Rzeczpospolitej Józef Janiczek, zastępca Naczelnego Dyrektora Bibliotek w 1946 r. stwierdzał, że bibliotek było mało, księgozbiory były ubogie i rozmieszczone nierównomiernie, źle się przedstawiał również stan czytelnictwa. Gdzie należało szukać jego zdaniem przyczyn tego stanu rzeczy?:

\footnotetext{
9 J. Augustyniak, Czytelnicy przedwojenni i dzisiejsi, „Książka i Kultura” 1945, nr 4-6, s. 2.

10 Po ogólnokrajowej naradzie bibliotekarzy, „Przegląd Biblioteczny” 1952, z. 2-3, s. 119; zob. również: Dekret o bibliotekach, „Biuletyn Księgarstwa Spółdzielczego” 1946, nr 5, s. 3.

11 AAN, Ministerstwo Oświaty (MO), sygn. 6847, Ustawa o bibliotekach i opiece nad zbiorami bibliotecznymi. Uzasadnienie, s. 110.
} 
Nie wchodząc w szczegóły wydaje się, że przede wszystkim w braku jasnej, przemyślanej i konsekwentnie realizowanej państwowej polityki bibliotecznej. Wskutek tego w ciągu 20 lat niepodległego bytu nie potrafiliśmy się zdobyć na wydanie ustawy bibliotecznej. W ciągu 20 lat państwowe czynniki biernie przyglądały się samorzutnym poczynaniom samorządu terytorialnego w zakresie masowego rozpowszechniania książki za pośrednictwem bibliotek oświatowych. Że w tych warunkach, przy naprawdę śmiesznie niskich kwotach wydatkowanych przez Skarb Państwa na akcję biblioteczną (od 30 do 100 tys. złotych rocznie w latach 1934-1939), osiągnięto mimo wszystko pewne pozytywne wyniki, jest to wyłączną zasługą pracowników oświatowych, a przede wszystkim bibliotekarzy, instruktorów oświaty pozaszkolnej, nauczycieli i przodowników młodzieży ${ }^{12}$.

Zaostrzenie zideologizowanej krytyki przedwojennego stanu bibliotek nastąpiło w latach 1948-1949. Jak twierdził na początku 1948 r. Adam Bromberg na łamach „Przeglądu Księgarskiego”, „nikła sieć biblioteczna” wynikała nie tylko z oszczędności budżetowych, ale również była ,jednym z elementów systemu sanacyjnego utrzymującego niski poziom oświaty w kraju o 30\% analfabetów i szerzącym się analfabetyzmie wtórnym"13. Podobne stanowisko zajął Józef Grycz, który w wydanym w 1954 r. skrypcie międzywojnie zaliczył do okresu imperializmu w dziejach książki, a piętnując fakt, że Polska nie doczekała się wówczas ustawy bibliotecznej na wzór tych, które uchwalono m.in. w Czechosłowacji, ZSRR, Bułgarii, Danii, Estonii i Finlandii pisał:

Aczkolwiek bowiem postępowe koła bibliotekarzy i oświatowców niezwłocznie po wojnie podjęły walkę w tym kierunku, wpływowe czynniki o wstecznej ideologii, strzegąc interesów reakcyjnych ugrupowań politycznych, stawiły tu zdecydowany opór. [...] Wynikiem tych sprzeczności był wysoce nieodpowiadający potrzebom stan bibliotekarstwa powszechnego w Polsce okresu międzywojennego ${ }^{14}$.

Dużo bardziej rzeczowy i napisany językiem mniej naznaczonym ideologicznie jest odpowiedni fragment podręcznika historii książki autorstwa Jana Muszkowskiego ${ }^{15}$.

Okazją do krytyki stanu bibliotek przed 1939 r. stały się obrady III plenum KC PZPR w 1949 r. To plenum, nazywane w żargonie specjalistów „czujnościowym", dawało ważny impuls dla ideologicznych czystek w państwie. Nieprzypadkowo w „Przeglądzie Bibliotecznym” ukazał się wtedy artykuł

12 J. Janiczek, Sprawy biblioteczne w ramach działalności Ministerstwa Oświaty, „Bibliotekarz" 1946, nr 1-2, s. 1.

13 A. Bromberg, Książka w Polsce odrodzonej, „Przegląd Księgarski” 1948, nr 3, s. 34-35.

14 J. Grycz, Krótki zarys historii książki i bibliotek, Warszawa 1954, s. 67. O wybitnej roli J. Grycza w tworzeniu podstaw bibliotekarstwa publicznego pisał Jacek Puchalski (Prace Józefa Grycza nad organizacja bibliotekarstwa publicznego w latach 1945-1949. Cz. I, „Z Badań nad Książką i Księgozbiorami Historycznymi” 2011, t. 5, s. 53-88; Cz. II, tamże 2012, t. 6, s. 79-112.

15 J. Muszkowski, Życie książki, wyd. 2 il. i rozsz., Kraków 1951, s. 267-269. 
Edwarda Iwańczaka, który ubolewał, że na „niektórych kierowniczych stanowiskach w bibliotekach" znajdują się ludzie, którzy dopuszczają do tego, aby w podległych im placówkach ,posiadających niekiedy duże zbiory książek była literatura bezwartościowa lub nawet wroga literatura faszystowska". Autor wymieniał autorów tych „faszystowskich” dzieł. Byli to: „Mniszkówna, Courts-Mahlerowa, Zarzycka, Marczyński, Ewers, Ossendowski” - „Fakty te świadczą zarówno o braku postawy ideologicznej jak i czujności bibliotekarza”. Biblioteki w Polsce Ludowej - konkludował - „są instrumentem walki klasowej i winny swoją rolę spełnić w ten sposób, aby obsłużyć najszersze masy robotniczo-chłopskie"16.

W Pamiętniku Konferencji Krynickiej (odbyła się 3-11 II 1951 r.), poświęconej bibliotekarstwu naukowemu Andrzej Grodek przestrzegał przed tym, że w bibliotece naukowej mogą się znaleźć czytelnicy, którzy książki „chcą wykorzystać do niewłaściwych celów”: „Do jakich bowiem celów potrzebne są emigracyjne kłamliwe rewelacje o Polsce, pisma Dmowskiego, Piłsudskiego lub ekonomia burżuazyjna - jak nie właśnie do wrogiej propagandy?". Świadomy ideologicznie bibliotekarz winien temu przeciwdziałać przez odpowiednie poradnictwo, propagandę i kontrolę ${ }^{17}$. Grodkowi wtórowała Jadwiga Filipkowska-Szemplińska, która w referacie wygłoszonym na Zjeździe Delegatów Związku Bibliotekarzy i Archiwistów Polskich (ZBiAP) we Wrocławiu 7 IV 1949 r. twierdziła, iż ,jeśli bibliotekarz wyda w ręce młodzieży studiującej na wyższej uczelni podręcznik «Teoria ekonomii» prof. [Adama] Heydla lub podręcznik ekonomii politycznej prof. [Frederica Charlesa] Benhama - nie wypełni swego zadania jako wychowawca młodzieży"18.

Tacy nowi bibliotekarze mieli zastąpić stare kadry sprzed 1939 r. i spowodować, że w okresie planu trzyletniego biblioteki

mimo poważnych osiągnięć, nie potrafily włączyć się w nurt zachodzących przemian.

Nie stały się orężem walki klasowej, nie były czynnikiem wychowawczym. [...] Wielu naszych bibliotekarzy, wychowanych w atmosferze sanacyjnego dwudziestolecia, cechuje jeszcze formalistyczne podejście do zagadnienia pracy bibliotecznej, brak im szerszych perspektyw spojrzenia, brak im właściwego uzbrojenia ideologicznego pisał Zbigniew Kempka w „Bibliotekarzu” w 1950 r., konkludując:

16 E. Iwańczak, III Plenum KC PZPR a zadania Związu Bibliotekarzy i Archiwistów Polskich, „Przegląd Biblioteczny” 1950, z. 2, s. 100-101.

17 A. Grodek, Rola i zadania bibliotek naukowych w budownictwie socjalizmu w naszym kraju, „Przegląd Biblioteczny” 1951, z. 3-4: Pamiętnik Konferencji Krynickiej 3-15 II 1951, s. $232-$ 233.

18 J. Filipkowska-Szemplińska, Zadania Z.B. i A.P. w Polsce Ludowej. Referat wygłoszony na Zjeździe Delegatów ZBiAP w Warszawie 7 IV 1949, „Bibliotekarz” 1949, nr 3-4, s. 39. Podobne wnioski - zob. A. Łuszpak, Obraz katalogów rzeczowych na łamach polskich czasopism bibliotekarskich w okresie stalinowskim, „Z Badań nad Książką i Księgozbiorami Historycznymi” 2016, t. 10 , s. $307-308$. 
Błędem minionego trzylecia w zakresie bibliotecznym było niedostateczne zwrócenie uwagi na zagadnienie oczyszczenia aparatu bibliotecznego z wrogich i szkodliwych jednostek, które pod płaszczykiem źle pojętej «fachowości» usiłowały prowadzić wrogą i szkodliwą robotę ${ }^{19}$.

Te ogólne dyrektywy poczęły wpływać na oceny i politykę kadrową wobec tej grupy zawodowej. Nieprzypadkowo wszak partyjny wizytator Państwowego Ośrodka Kształcenia Bibliotekarzy w Jarocinie w 1950 r. za kryterium dyskwalifikujące jedną z wykładowczyń uczynił to, że najchętniej cytowała przedwojenne wydawnictwa Arcta nie czyniąc żadnej wzmianki o literaturze radzieckiej ${ }^{20}$.

Zasygnalizowany motyw wykształcenia nowego typu bibliotekarza znalazł się w referacie Włodzimierza Sokorskiego prawdopodobnie z 1952 r., zachowanym w skrócie w aktach Centralnego Zarządu Bibliotek. Jego autor pisał, że „,na pracy naszej ciągle jeszcze tu i ówdzie ciąży błędne przekonanie, wyniesione z okresu Polski kapitalistycznej - że zadaniem biblioteki i bibliotekarza jest udostępnić zbiory biblioteczne, a nie czynnie o nie walczyć”. Trzeba bowiem:

do końca przezwyciężyć błędną kapitalistyczną postawę bibliotekarza, pracującego w przekonaniu, że biblioteka jest «apolityczną», «obiektywną», «świątynią» wiedzy i kultury, stojącą «ponad» wszelkimi sprawami aktualnie bieżącego życia. Że nie on do czytelnika, a czytelnik do niego przyjść powinien ${ }^{21}$.

Oczyszczeniu i wychowaniu według nowych zasad miał być poddany nie tylko „aparat biblioteczny”. Z bibliotek miały być także usunięte książki „wrogie ustrojowi ludowemu i społecznie szkodliwe”. Czy ich listy zawierały liczną reprezentację dzieł opublikowanych przed wojną? Jak na razie taka analiza nie została przeprowadzona, choć najprawdopodobniej jest możli$w^{22}$. Na potrzeby niniejszych badań odnalazłem jak się wydaje dość typowy spis książek z Miejskiej Biblioteki Publicznej w Śmiglu w powiecie kościańskim (województwo poznańskie) z września 1949 r., które na polecenie

19 Z. Kempka, Rola bibliotek w Planie 6-letnim, „Bibliotekarz” 1950, nr 3-4, s. 35; A. Luszpak, dz. cyt., s. 309.

20 AAN, KC PZPR, sygn. 237/XVII-229, Notatka z wizytacji Państwowego Ośrodka Kształcenia Bibliotekarzy w Jarocinie, odbytej w dniu 26 i 27. 10. 1950 r., k. 84.

21 AAN, Ministerstwo Kultury i Sztuki, Centralny Zarząd Bibliotek (CZB), sygn. 49, W. Sokorski, Bibliotekarz i problem czytelnictwa (skrót referatu), k. 12. Jest to prawdopodobnie skrót referatu wygłoszonego na Ogólnokrajowej Naradzie Bibliotekarzy w maju 1952 r. Na ten temat zob. również: Zadania bibliotekarzy, „Poradnik Bibliotekarza” 1952, nr 8, s. 169-172; Z. Rodziewicz, Zagadnienie kadr bibliotekarskich na Ogólnokrajowej Naradzie Bibliotekarzy, tamże, s. 173-177; W. Sokorski, Bibliotekarstwo w Polsce Ludowej, [w:] Zagadnienia czytelnictwa w Polsce Ludowej. Ogólnopolska Narada Bibliotekarzy w Warszawie $w$ dn. 29-30 maja 1952 r., [red. A. Radłowska], Warszawa 1952, s. 39.

22 Wymaga to jednak analizy wielu wykazów liczących zwykle po kilkaset pozycji, najczęściej pozbawionych informacji o dacie wydania. Akta Komisji Oceny Wycofanych Wydawnictw zachowane są w AAN, w zespole CUWPGiK (sygn. 73). 
odpowiedniej komisji miały być „zniszczone przez spalenie” [sic!]. Na 124 pozycje co najmniej 23 (blisko 1/5) były opublikowane w latach 1918-1939. Dominują wśród nich dzieła na tematy religijne i (lub) pisane przez księży ${ }^{23}$. Wstępna kwerenda list książek wycofywanych zdaje się wskazywać, że wśród nich stosunkowo najwięcej można odnaleźć takich, które ukazały się po wojnie, w latach 1945-1949. Czasami te listy zaopatrzone są w uzasadnienia. W przypadku książek naukowych częstym zarzutem jest niemarksistowskie (idealistyczne) ujęcie tematu, reakcyjność (np. Kultura ludowa i ludoznawstwo w Polsce Jana Bystronia i Witolda Dynowskiego) i nieaktualność ${ }^{24}$.

W latach 50. w artykułach na temat bibliotekarstwa pojawił się nurt triumfalizmu. Wyliczano osiągnięcia tego okresu, których wartość była jeszcze większa na tle mizerii Polski przedwojennej:

Bibliotekarstwo polskie ma za sobą znaczne osiągnięcia w zestawieniu z przedwojennym wczoraj. Ilość bibliotek, ilość książek, ilość czytelników wzrosła w stosunku do liczb sprzed września 1939 r. Jest to wyraz nowych warunków ustrojowych, ale także wynik wysiłków bibliotekarzy i powód do słusznej dumy ${ }^{25}$.

Polska przedwojenna była pokazywana jako kraj, w którym nie było masowego czytelnictwa (nie przekraczało 4\%). Oprócz nędzy materialnej jedną $\mathrm{z}$ akcentowanych przyczyn takiego stanu rzeczy miało być nieodnajdywanie przez masy robotnicze i chłopskie w „ówczesnej literaturze odpowiednich treści. Literatura przedstawiała świat im obcy lub w fałszywym ujęciu, ideologicznie wrogim. [...] W stanie głodu i beznadziei nie czyta się literatury pięknej". To dzięki Polsce Ludowej wzrosły nakłady książek, rozpoczęto skuteczne zwalczanie analfabetyzmu i tworzenie sieci bibliotecznej. Aby jednak robotnik znalazł w literaturze polskiej odpowiednią dla niego ,strawę duchową”, to „musi ona się zmienić, odejść od swych mieszczańskich korzeni". Musi się nie tylko tematycznie dostosować do masowego czytelnika, ale również zróżnicować pod względem poziomu. Na poziomie podstawowym musi być ona ,jasna i nieskomplikowana"26.

Te wszystkie cechy binarnego, czarno-białego postrzegania problemów bibliotek, bibliotekarstwa i czytelnictwa znalazły „krystalicznie klarowny” wyraz w cytowanym już skrócie referatu W. Sokorskiego, według którego:

23 AAN, KC PZPR, sygn. 237/XVII-229, Spis książek, które na polecenie komisji kontrolnej zostały wyłączone z użytku bibliotecznego z poleceniem ich zniszczenia przez spalenie, Śmigiel, 8 IX 1949, k. 37-38. Na temat tej akcji w skali ogólnopolskiej - zob. S. Kondek, Papierowa rewolucja. Oficjalny obieg książek w Polsce w latach 1948-1955, Warszawa 1999, s. 146-147.

24 AAN, CUWPGiK, sygn. 84, Lista książek zdezaktualizowanych, k. 25-31; tamże, Lista książek do wycofania, k. 6-24; tamże, Spis publikacji „W[iedzy]P[owszechnej] wycofanych i przeznaczonych do wycofania, k. 146-157.

25 Z. Daszkowski, O wspólpracę bibliotek naukowych z siecią bibliotek powszechnych (po konferencji w Jarocinie), „Przegląd Biblioteczny” 1954, z. 2, s. 121.

26 K. Wojciechowski, Potrzeby czytelnictwa masowego, ,Bibliotekarz” 1950, nr 5-6, s. 66-70. 
Zastój bibliotekarstwa polskiego w okresie przedwrześniowym oraz imponujący jego rozwój po objęciu władzy przez lud polski ukazuje, jak burżuazja tłumiła prawdziwy rozwój oświaty, i jak władza ludowa stworzyła warunki do rozkwitu bibliotek, jako instytucji upowszechnienia oświaty i kultury.

Prelegent konstatował dalej, że:

Rządy sanacyjne nie chciały dopuścić do uchwalenia ustawy bibliotecznej, gdyż nie odpowiadało to ich interesom. [...] Biblioteki w okresie międzywojennym były nikłe i nie powiązane we współpracującą sieć, nie posiadały trwałych podstaw finansowych, ani wykwalifikowanego personelu. [...]. Większość bibliotek o charakterze powszechnym skupiała się w okresie międzywojennym w rękach prywatnych osób, stanowiąc właściwie placówki handlowe, nie mówiąc już o tym, że w swej większości były w rękach reakcyjnych organizacyj społecznych, takich jak macierz szkolna itp. ${ }^{27}$

W podobnym tonie wypowiadał się Adam Stebelski, przewodniczący Zarządu Głównego ZBiAP w trakcie Walnego Zgromadzenia organizacji w końcu 1953 r. Twierdził, że w okresie międzywojennym, czyli w czasach „dominacji w Polsce reakcji i Ciemnogrodu” nikt, poza kołem ludzi światłych i postępowych ,nie interesował się poważnie sprawą bibliotek i upowszechniania czytelnictwa, traktując to jako niebezpieczne nowatorstwo i groźny radykalizm lub - jak maniactwo ludzi naiwnych lub lekkomyślnych". Z drugiej strony Stebelski odwoływał się z szacunkiem do przedwojennych tradycji Związku Bibliotekarzy Polskich i wcześniejszych odeń Kół Bibliotekarzy twierdząc, że ,tradycja to ładna"28.

Zdecydowanie przeważająca jednak ideologiczna wizja spraw bibliotek miała się stopniowo przekładać na szczegółowe rozwiązania dotyczące bibliologii i bibliotekarstwa. Nie jest wszak przypadkiem, że Marian Smereka, kierownik Oddziału Katalogów Biblioteki Uniwersyteckiej we Wrocławiu w okresie stalinizmu proponował na przykład, aby na kartach przewodnich katalogów rzeczowych zamiast hasła „Polska w latach 1918-1939” umieszczać „Polska obszarniczo-burżuazyjna”, a zamiast hasła „strajk” - ,walka klasy robotniczej z rządem obszarniczym"29.

Jeszcze w roku 1948 było możliwe w miarę wyważone pisanie o osiągnięciach Drugiej Rzeczpospolitej w zakresie przysposobienia czytelniczego i sukcesach w bibliotekarskich pracach normalizacyjnych ${ }^{30}$. Podobnie zobiektywizowanych opinii z początków lat pięćdziesiątych nie udało się już odnaleźć.

\footnotetext{
27 AAN, CZB, 49, W. Sokorski, Bibliotekarz..., k. 1-2.

28 AAN, KC PZPR, 237/XVIII-14, [Referat A. Stebelskiego na Walne Zgromadzenia ZBiAP, grudzień 1953], k. 49.

29 A. Łuszpak, Katalogi rzeczowe w stużbie ideologii (na przykladzie Biblioteki Uniwersyteckiej we Wrocławiu w latach pięćdziesiatych XX wieku), [w:] Nie po myśli władzy..., s. 255.

30 M. Dembowska, Przysposobienie czytelnicze młodzieży szkolnej, „Biuletyn Państwowego Instytutu Książki" 1948, nr 3, s. 1-3; Prace normalizacyjne w zakresie bibliotekarstwa (Karty kata-
} 
Nieprzypadkowo to w apogeum stalinizmu dużą popularność uzyskują bibliografie zalecające, które, wzorem doświadczeń sowieckich, miały stać się narzędziem walki ideologicznej o „konkretne osiągnięcia natury społeczno-politycznej w zakresie pracy badawczej i propagandowej"31.

Ten kierunek myślenia, w którym najważniejszą cechą bibliografii zalecającej jest ,ideologiczne kryterium doboru i oceny książki mającej służyć socjalistycznemu wychowaniu, socjalistycznemu budownictwu"32 był fragmentem szerszego procesu ideologicznego przewartościowania bibliologii. Najklarowniej ten kierunek myślenia zaprezentował Władysław Bieńkowski, dyrektor Biblioteki Narodowej, w wydanej w 1953 r. broszurze O pseudo-nauce bibliologii i o najpilniejszych zadaniach bibliografi ${ }^{33}$. Obok wielu bardzo ostrych sądów na temat bibliologii jako takiej jej autor oskarżał większość polskich przedwojennych teoretyków tej nauki o formalizm, „tchórzliwe obchodzenie zagadnienia stosunku książki do jej treści”. Jako negatywny wzór pod tym względem posłużył Mieczysław Rulikowski, autor rozprawy Księgoznawstwo, przeszłość oraz stan obecny wiedzy o książce i nowe w niej kierunki (Warszawa 1936). Bieńkowski szydził z bibliologii, która szerzyć miała „reakcyjną ideologię społeczną”. Twierdził, że jako nauka nie istnieje. Ten negatywny stosunek do uczonych myślących podobnie jak napiętnowany Rulikowski obejmował niemal wszystkich z nich, zajmujących się tą dziedziną wiedzy w dwudziestoleciu międzywojennym z wyjątkiem Kazimierza Piekarskiego, który miał wyrażać już w latach 30 . wątpliwości co do naukowego statusu bibliologii.

Co gorsza, zdaniem Bieńkowskiego, ten „formalistyczny” sposób myślenia przetrwał aż do początków lat 50 i znalazł wyraz w publikowanych wówczas pracach Stefana Vrtela-Wierczyńskiego (Teoria bibliografii w zarysie, Wrocław 1951), J. Muszkowskiego (Życie ksiażki, Kraków 1951) i Adama Łysakowskiego (Określenie bibliografii. Przedmiot, metody i zadania na tle nauki o książce, „Biuletyn Instytutu Bibliograficznego” 1950, t. 3, nr 2, s. 1543). Zerwanie z tą tradycją wymagało od bibliografa oceny wartości naukowej

logowe czasopism. Karty akcesyjne czasopism), Warszawa 1948, Biuletyn Państwowego Instytutu Książki, t. 1, nr 7, s. 1-2.

31 A. Łysakowski, Zagadnienie treści i wartości książki w bibliografii, „Biuletyn Instytutu Bibliograficznego" 1953, nr 9, s. 230. Zob. również: W.N. Denisew, Organizacja bibliografii w ZSRR, thum. J. Gruszecka, Warszawa 1951, Biuletyn Instytutu Bibliograficznego, t. 3, nr 4, s. 65-90.

32 W. Bieńkowski, O pseudo-nauce bibliologii $i$ o najpilniejszych zadaniach bibliografii, Warszawa 1953, s. 48.

33 Broszura powstała na podstawie referatu wygłoszonego dla członków Warszawskiego Koła Związku Bibliotekarzy i Archiwistów w ramach przygotowań do I Kongresu Nauki Polskiej w 1951 r. Zob. J. Sadowska, Marksistowskie poglady Władysława Bieńkowskiego w teorii i praktyce bibliotecznej, [w:] Ksiażka zawsze obecna. Prace ofiarowane Profesorowi Krzysztofowi Migoniowi, Wrocław 2010, s. 341-342. Za zwrócenie uwagi na tę publikację dziękuję prof. Markowi Toberze. 
„bibliografowanej książki”, wskazania co jest w niej nowego w stosunku do dotychczasowych badań. Ponadto W. Bieńkowski podkreślał, że: „Bibliograf musi ocenić ideologiczną (filozoficzną) postawę, odcyfrować polityczne, klasowe oblicze autora" $"$.

Jak te ogólne założenia przekładały się na praktykę bibliografii? Najlepiej widać to we wspomnianych już bibliografiach zalecających ${ }^{35}$. Co prawda nie udało się odnaleźć takiej, która by była poświęcona w całości problemom Polski przedwojennej, ale to nie znaczy, że międzywojnie się w nich nie pojawia. Typowy przykład stanowi poradnik bibliograficzny zatytułowany Osiem lat Polski Ludowej (Warszawa 1952). Zgodnie z zasadą binarności w wielu zamieszczonych tam notach o książkach, broszurach i artykułach, które koncentrują się na osiągnięciach powojennej Polski krytyczna wizja dwudziestolecia międzywojennego stanowi punkt wyjścia. Na tym tle osiągnięcia „władzy ludowej” mają się jawić jako szczególnie spektakularne. Jedynymi samodzielnymi pozycjami bibliograficznymi, które poświęcone zostały w całości międzywojniu są wspomnienia działaczy Komunistycznej Partii Polski (KPP) i artykuł Stefana Jędrychowskiego o konstytucjach Polski przedwrześniowej, stawiający tezę, że obie ustawy zasadnicze: z 1921 i 1935 r. były „konstytucjami wyzysku mas pracujących”36.

Podobny schemat zastosowano $\mathrm{w}$ poradniku bibliograficznym na temat dziesięciolecia Polski Ludowej, wydanym przez Instytut Bibliograficzny (IB) BN w Warszawie ${ }^{37}$. Pozycje tam wymienione są zaopatrzone w streszczenia, które zawierają konsekwentną wizję przedwojennej Polski. Tak jak w przypadku omówionym wcześniej miał być to okres aktywności KPP, która niezłomnie walczyła o szczęście i dobrobyt ludzi pracy ${ }^{38}$. To w jej szeregach Bolesław Bierut prowadził walkę o narodowe i społeczne wyzwolenie ${ }^{39}$. Niektóre z rozdziałów poradnika są poprzedzone zestawieniem liczb, które miały wykazać zacofanie społeczne, gospodarcze i kulturalne przedwojennej Polski w stosunku do Polski Ludowej w okresie planu sześcioletniego. W rozdziale zatytułowanym Rolnictwo i przebudowa wsi ulubionym zabiegiem w opisach adnotowanych pozycji bibliograficznych jest przeciwstawienie „zacofania gospodarczego i nędzy wsi w okresie rządów burżuazyjno-obszarniczych" sytuacji chłopów i osiągnięciom wsi w Polsce powojennej ${ }^{40}$. W rozdziale

34 Tamże, s. 41.

35 Na ten temat zob. J. Sadowska, Bibliografia zalecająca w Polsce, „Przegląd Biblioteczny” 2016, z. 2, s. 177-195.

36 Osiem lat Polski Ludowej. Poradnik bibliograficzny, Warszawa 1952, s. 5, 16.

37 Dziesięć lat Polski Ludowej. Poradnik bibliograficzny, Warszawa 1954.

38 Tamże, s. 6.

39 Tamże, s. 9.

40 Tamże, s. 29-31. 
poświęconym kulturze, oświacie i nauce można znaleźć passus: „w przeciwieństwie do Polski międzywojennej Polska Ludowa potrzebuje wielu tysięcy inżynierów i techników, na których czekają nowe i stare zakłady produkcyjne, rolnictwo, transport" 41 .

W innym poradniku bibliograficznym, pt. Kobieta wczoraj $i$ dziś, wydanym również przez IB BN w 1954 r., w dziale Z niedawnej przeszłości obok Marty Elizy Orzeszkowej, Siłaczki Stefana Żeromskiego i Emancypantek Bolesława Prusa pojawia się m.in. Drewniany różaniec Natalii Rolleczek charakteryzowany w następujący sposób:

Opowiadania osnute na tle wspomnień z własnego dzieciństwa autorki charakteryzują wymownie sanacyjną dobroczynność i filantropię. Głęboko utkwiły w pamięci autorki doznane upokorzenia, krzywdy i wzgarda oraz osobliwe metody wychowawcze stosowane przez jaśniepańskie filantropki, dobroczynne stowarzyszenia i zakony ${ }^{42}$.

Ten sam manichejski obraz międzywojnia (uciśniony lud i uciskające go „klasy posiadające”) dominuje w zestawach lektur proponowanych w ramach licznych konkursów organizowanych dla „nowego czytelnika"43. Temu schematowi hołdują w oficjalnych wystąpieniach uczestnicy licznych zlotów czytelniczych. Oto na przykład aktywiści wiejscy, którzy brali udział w III Krajowym Zlocie Wiejskich Przodowników Czytelnictwa przeciwstawiają książki dawne (w ich rozumieniu te, które czytali przed wojną) - współczesnym, spełniającym ważne funkcje praktyczne. Jedna z uczestniczek twierdzi:

Ja czytała książki dawniej, ale tamte książki nie były takie jak dzisiaj, które nas pouczają o wszystkim, o rolnictwie, o hodowli. Książka nam dużo pomaga. Pomaga również i starszym. Ja mam dzieci. Wychowałam je przy pomocy książek, czytałam im różne opowiadania ${ }^{44}$.

Członek spółdzielni produkcyjnej mówił: „Niestety książka była w dawniejszych czasach niedostępna, nie tak, jak dziś, że książka sama przychodzi do ręki, żeby ją przeczytać" 45 .

W sposób stosunkowo najbardziej spektakularny i wzorowy z punktu widzenia stalinowskiej propagandy o różnicy między książką przedwojenną i powojenną mówił uczestnik zlotu z Białostockiego:

W referacie było mówione o książkach przedwojennych, o książkach takich autorów jak

Courths Mahlerowa, jak Cooper i Baxter. Trzeba stwierdzić, że te książki nic nam nie

41 Tamże, s. 37.

42 Kobieta wczoraj i dziś. Poradnik bibliograficzny, Warszawa 1954, s. 5-6.

43 Zob. m.in.: AAN, KC PZPR, sygn. 237/XIIII-14, Wykaz książek do IV etapu konkursu czytelniczego (22 VII 1953-22 VII 1954), b.d. i m.r., k. 232-240.

44 AAN, CZB, 23, Stenogram z III Zlotu Wiejskich Przodowników Czytelnictwa w dniach 26 i 27 czerwca 1954, k. 10.

45 Tamże, k. 12. 
dawały, że pokazywały [...] nam świat nierealny, pokazywały nam życie, jakim ono nie jest. Dzisiejsze książki pokazują nam życie takie jak ono wygląda i jak ma wyglądać, poddają nam gotowe rady do zastosowania w naszym życiu. I właśnie dzięki takim książkom, jak Wasilewskiej «Ojczyzna», Szołochowa «Zaorany ugór», Ażajewa «Daleko od Moskwy», te książki pomogły nam stworzyć spółdzielnię produkcyjną ${ }^{46}$.

Przytoczone argumenty świadczą, że wraz z postępami rewolucji stalinowskiej obraz bibliotek, bibliologii i bibliotekarstwa był coraz bardziej wyostrzony i malowany w coraz ciemniejszych barwach.

\section{Wydawcy i księgarze}

Większość argumentów, jakie wytaczano przeciwko międzywojennemu ruchowi wydawniczemu można odnaleźć już w 1945 r. w programowym artykule Zofii Dembińskiej o założeniach ideowych „Czytelnika”. Udowadniając, że reprezentowana przez nią spółdzielnia wydawnicza jest odpowiedzią na dotychczasowe doświadczenia funkcjonowania wydawnictw w przedwojennej Polsce pisała:

Kto wydawał dotychczas książki w Polsce? Wydawał je kapitalista. Była to jedna z form puszczania w ruch kapitału, tak samo dobra, jak fabryki gumy do żucia, czy płyt gramofonowych. Dlatego brali się do tej akcji ludzie bez żadnej idei społecznej. Łatwy, szybki dochód decydował o tym, co miało być wydane. Stąd np. przewaga przekładów z języków obcych, bez względu na celowość (gotowy materiał, gotowa propaganda, małe ryzyko), stąd nadmiar książek «meblowych», to jest wielotomowych, bezwartościowych wydawnictw w barwnych złoconych okładkach, dla ozdoby szaf bibliotecznych, stąd, co gorsza, pornografia, kryminalistyka i tandeta naukowa. Wydawców zasłużonych dla kultury polskiej można było policzyć na palcach. Gdzież plan wydawniczy ogólnopolski, równomierne obsłużenie wszystkich warstw, zawodów i grup społecznych? Byliśmy wszyscy skazani na czytanie tego, co nam narzucił prywatny wydawca ${ }^{47}$.

Tej opinii wtórował A. Bromberg, który twierdził, że musiano

uciekać się do podstępów, aby wydać książkę lewicową. [...] Wydawcy zalewali natomiast rynek tysiącami książek bezwartościowych: mnożyły się detektywistyczne romanse i ckliwe powieścidła «pisarzy» typu Marczyńskiego czy Zarzyckiej, Wallace’a czy Courths-Mahler. W literaturze pięknej dominowała ,książka licha, obliczona na bezkrytycznego czytelnika, w dziedzinie zaś książki naukowej - książka odpowiadająca ideologicznie reżymowi sanacyjnemu" ${ }^{48}$.

Ta krytyczna ocena rynku książki w Drugiej Rzeczpospolitej zawierała zarzut, że ówczesną, „rzeczywistość wydawniczą” cechowała „niezmiernie

46 Tamże, k. 107.

47 Z. Dembińska, Założenia ideowe «Czytelnika», „Książka i Kultura” 1945, nr 1, s. 5.

48 A. Bromberg, dz. cyt., s. 35. 
niska produkcja i nieprawdopodobnie nikła wysokość nakładów, powodowana w głównej mierze brakiem odbiorców". Jednocześnie już przed wojną „poczęto zdawać sobie sprawę”, że „pisarz, wydawca, księgarz i bibliotekarz ponoszą odpowiedzialność za losy współczesnej i przyszłej kultury. W imię tych odpowiedzialności pomiędzy tymi czynnikami musi nastąpić ścisłe porozumienie i stała, na długą metę obliczona współpraca". To Polska Ludowa miała realizować postulat owego porozumienia. Jego początkiem miało być ustalenie listy najpotrzebniejszych książek, które powinny być wydrukowane w pierwszej kolejności w kilkudziesięciotysięcznych nakładach dla zasilenia bibliotek wszelkich typów, w tym szczególnie szkolnych i powiatowych ${ }^{49}$.

Tworząc binarną opozycję: Polska Ludowa - Polska sanacyjna, wskazywano na różnice w produkcji wydawniczej (rok 1937 - 29 mln egzemplarzy książek, broszur podręczników szkolnych, wydawnictw religijnych; 1948 62,5 mln, 1949 - $73 \mathrm{mln}, 1950$ - $85 \mathrm{mln})^{50}$.

Podstawowa różnica, jaka miała zachodzić między wydawaniem i dystrybucją książek w Drugiej Rzeczypospolitej i Polsce Ludowej dotyczyła roli rynku i planu wydawniczego. W dwudziestoleciu międzywojennym schlebianie gustom mieszczańskiej publiczności miało powodować nadmierny nacisk na wydawanie literatury brukowej. Po wojnie to władze miały racjonalnie tworzyć plan wydawniczy, który obejmował dzieła najwartościowsze. Jeszcze jednak w 1947 r. w prasie branżowej deklaracje zgody na taki plan współistniały z brakiem wypracowania „jakiegoś konkretnego systemu, jeśli idzie o metodę planowania”51.

Antynomia planu wydawniczego w stosunku do „przedwojennego”, ale także tuż powojennego chaosu została bardzo wyraźnie zaakcentowana w cytowanym tekście A. Bromberga, który pisał:

rok 1948 będzie rokiem planu wydawniczego - państwo zrobi użytek z tej zdobyczy demokratycznej, jaką jest przejęcie z rąk prywatnych większych drukarń, papieru i surowców. Od dnia 1 stycznia br. nikt już w Polsce nie ma prawa używać papieru na druk rzeczy niepotrzebnych, bezwartościowych. Zezwoleń na użycie papieru drukowego udziela specjalna komisja międzyministerialna z udziałem autorów i wydawców. Komisja ta ocenia hierarchię potrzeb i nie pozwoli marnować papieru na szkodliwą czy pornograficzną literaturę. Wysiłek, ofiarność robotnika papierni i drukarni muszą być wykorzystane celowo - nie mogą się ukazywać na bezcennym dla nas papierze powieścidła typu «Barbara kłamiesz» czy też senniki egipskie. Nie otrzyma prawa zadrukowania papieru jasnowidz Pyffeloi itp., itp. ${ }^{52}$

Ten nurt krytyki rzekomej bezplanowości ruchu wydawniczego, mimo zupełnie innych deklaracji, zaostrzył się w 1948 r. i był użyty jako oręż w walce

49 Sprawy książki w prasie, „Biuletyn Księgarstwa Spółdzielczego” 1946, nr 4, s. 6.

50 Z. Kempka, dz. cyt., s. 40.

51 A. Klimowicz, W sprawie planu wydawniczego, „Biuletyn Księgarstwa Spółdzielczego” 1947, nr 7/8, s. 103.

52 A. Bromberg, dz. cyt., s. 51. 
z wydawnictwami prywatnymi, próbującymi kontynuować model funkcjonowania z okresu przed 1939 r. To one miały w pierwszym rzędzie przedkładać „zysk, szybkość i łatwość obrotu” nad „wszelką ideę przewodnią”, czym zresztą rzekomo „zarażały” również wydawnictwa państwowe i spółdzielcze. Wprowadzenie planu wydawniczego miało zlikwidować „stan chaosu i konkurencji”, ochronić przed ,żerowaniem na wydawniczych łatwiznach" ${ }^{53}$. Wydawnictwa państwowe i społeczne, powstałe po II wojnie światowej jako „wydawnictwa nowego typu” miały służyć misji upowszechnienia kultury, produkować bez lub z minimalnym zyskiem ${ }^{54}$.

Potanieniu książki miało również służyć usunięcie „pasożytniczego procentu księgarskiego", co zamierzano osiągnąć przez likwidację księgarni prywatnych i utworzenie wspomnianej już państwowej Centrali Obrotu Księgarskiego „Dom Książki”,55.

W zakresie organizacyjnym odwołaniem do międzywojnia było reaktywowanie Związku Księgarzy Polskich (ZKP), którego pierwsze walne zgromadzenie obradowało 23 IX 1945 r. a prezesem został Stanisław Arct. Konsekwentna zmiana koncepcji funkcjonowania ruchu księgarskiego (przyspieszona po 1949 r. etatyzacja) i organizacji społecznych w ogóle doprowadziła do likwidacji ZKP ${ }^{56}$.

Przedwojnie i pierwsze lata Polski Ludowej miały także różnić się w sposobie traktowania autorów książek. Cytowana Z. Dembińska już w 1945 r. krytykowała stosunek wydawców do nich:

Nawet Żeromski, człowiek i pisarz najmniej zainteresowany w tym, co się zwykło nazywać dobrem materialnym, pisarz poczytny i zapewniający wydawcom wielkie dochody, nie wahał się nazwać ich «wydławcami». W takich warunkach życie autorów kształtowało się jako ustawiczna walka o wydarcie kilku godzin czasu pracy zarobkowej, w której większość z nich szukać musiała utrzymania dla siebie i swoich rodzin. Jakże często były wypadki, że autor, pobrawszy całe honorarium zaliczkami z góry, był w sposób dość paradoksalny smutnym świadkiem wielkiego sukcesu wydawniczego swojej pracy. Wydawca zbierał żniwo, autor tonął w długach.

Jednym z następstw tego stanu rzeczy, poza trudnościami rozwojowymi twórczości literackiej i naukowej

53 H. Wolpe, $W$ sprawie naszego ruchu wydawniczego, „Praca Księgarska. Biuletyn Księgarstwa Spółdzielczego" 1948, nr 11, s. 197.

54 A. Bromberg, dz. cyt., s. 35.

55 S. Kondek, Papierowa rewolucja..., s. 56.

56 AAN, Związek Księgarzy Polskich (ZKP), sygn. 6, Protokół z Walnego Zgromadzenia członków Związku Księgarzy Polskich z 23 września 1945, k. 1; tamże, Uchwała Walnego Zgromadzenia Likwidacyjnego Związku Księgarzy Polskich z dn. 10 grudnia 1950 r., k. 53. Zob. M. Tobera, Wtadza i księgarze..., s. 108-109. 
był fakt, że niedola materialna odbierała ludziom pióra niezależność myśli, skłaniała do oddawania swej wiedzy i talentów na usługi klasy rządzącej, która tanim kosztem znajdowała w nich szermierzy i rzeczników swoich interesów ${ }^{57}$.

„Czytelnik” pragnął zerwać z tą tradycją. Poczucie obowiązku społecznego miało nakazywać wydawnictwu roztoczenie opieki nad pisarzami, w tym również nad rodzinami tych spośród nich, którzy nie żyli ${ }^{58}$.

Ten atak na prywatnych wydawców, wzbogaconych rzekomo na skupowaniu w czasie wojny, po zaniżonych cenach, praw do wydawania dzieł znanych autorów $^{59}$ przybrał postać konfliktu między wydawcą Eugeniuszem Kuthanem i Janem Brzechwą. Popularny pisarz dla dzieci skarżył się, że w czasie wojny zmuszony był sprzedać prawa do piętnastu utworów, a wydawca nie chciał uzupełnić wypłaconych wtedy honorariów do wysokości przyjętej po wojnie. Rozpętana nagonka prasowa miała uderzyć i zdyskredytować prywatne wydawnictwa ${ }^{60}$.

Jest rzeczą charakterystyczną, że w ówczesnej narracji na temat spraw książek nie pojawia się jakakolwiek próba obrony cenzury powojennej, a jednocześnie przedmiotem krytyki jest cenzura przedwojenna. Za jej pomoca „dyktatura sanacyjna” miała „trzymać w karbach” ówczesne wydawnictwa. Jak pisał cytowany A. Bromberg, książki,

które śmielej stawiały sprawy społeczne, które pisały prawdę o wyzysku kapitalistycznym, o walce robotniczej, o Związku Radzieckim - ulegały konfiskacie. Gdy ze względu na popularność beletrystyki radzieckiej zezwalano na wydawanie niektórych książek, tłumaczonych z rosyjskiego - osławiony cenzor warszawski, Biernacki, dokonywał fantastycznych skrótów i zmian, częstokroć zniekształcających sens (takich skreśleń dokonano np. w «Matce» Gorkiego, w «Czapajewie» Furmanowa i wielu innych). W «Chlebie» Tołstoja rozmowę Lenina ze Stalinem kazał cenzor przerobić na telefoniczną rozmowę z ...nieznanym rozmówcą.

A. Bromberg twierdził, że dławienie kultury odbywało się również za pośrednictwem samych wydawców, ,którzy w ogromnej większości szli po linii polityki rządu. Wydawnictwa demokratyczne, postępowe z trudem znajdowały wydawcę" 61.

\section{Konkluzje}

Czy poczynione ustalenia układają się w jakąś prawidłowość? Czy na ich podstawie można odpowiedzieć na postawione wcześniej pytania badawcze?

57 Z. Dembińska, dz. cyt., s. 5.

58 Tamże.

59 O skupowaniu tych praw wspomina Józef Zaremba, Było i tak. Wspomnienia, Wrocław 1976, s. 347-348.

60 T. Kondek, Władza..., s. 148-153.

61 A. Bromberg, dz. cyt., s. 35. 
Wydaje się, że uprawniają one do kilku podstawowych konkluzji.

1. Przeprowadzona w latach 1945-1956 w dyskursie oficjalnym reinterpretacja tradycji Drugiej Rzeczpospolitej w zakresie spraw książki zmierzała do skontrastowania przedwojennych, wartościowanych niemal wyłącznie negatywnie doświadczeń z ocenianą z reguły pozytywnie polityką powojenną. Selekcja porównywanych treści była tak dokonana, aby przekonać odbiorców o wyższości rozwiązań przyjmowanych po wojnie i stanowić argument uzasadniający ich przyjęcie w oparciu o słuszne wnioski wyciągane z doświadczeń przeszłości. Stąd na przykład stosunkowo dużo pisano o zaletach ustawy o bibliotekach, o planie wydawniczym, a pomijano niewygodny z tego punktu widzenia problem funkcjonowania powojennej cenzury.

2. Argumenty używane w krytyce sytuacji książki przed wojną pojawiały się w szerokim kontekście opinii na temat problemów kultury i oświaty w latach 1918-1939, a te były argumentem w negatywnej ocenie Drugiej Rzeczpospolitej jako takiej, z jej systemem politycznym, gospodarczym i nierównościami społecznymi.

3. Negatywne oceny sytuacji książki przed wojną zostały wykorzystane jako uzasadnienie części zmian na tym polu, dokonywanych w okresie forsownej stalinizacji, a szczególnie w latach 1948-1950. Krytykowano bowiem dokonania okresu tuż powojennego przede wszystkim z tego powodu, że stanowiły w pewnej mierze, zwłaszcza w zakresie ruchu wydawniczego i księgarskiego, próbę reanimowania rozwiązań przedwojennych, opartych o prywatną inicjatywę i zasady rynkowe.

4. Odwoływanie się do propagandowo wykrzywionego obrazu sytuacji książki w Polsce przedwojennej nasilało się w okresie dokonywania najważniejszych, rewolucyjnych przemian w tym zakresie, których istotą było biurokratyczne planowanie, etatyzacja i kontrola procesów jej tworzenia, produkcji, popularyzacji, sprzedaży i dystrybucji.

5. Problemem wymagającym dalszych badań jest odpowiedź na pytanie, na ile argumenty używane w propagandowym ,zaczernianiu” obrazu spraw książki w Drugiej Rzeczpospolitej mogły być przekonujące dla tych, do których miały docierać. Ich siła leżała najpewniej także w ,ziarnach prawdy”, które zawierały. Trudno zaprzeczyć, że na przykład czytelnictwo w przedwojennej Polsce było dość ograniczone, a skala analfabetyzmu - bardzo duża. I trudno również dyskutować z faktem, że w latach 1945-1954 założono połowę (5110) wszystkich publicznych bibliotek i filii bibliotecznych powstałych w Polsce do 1989 r. $(10313)^{62}$. Stalinowskie teksty propagandowe dziś wydają nam się aberracyjne i budzą najczęściej drwinę, ale musimy pamiętać, że nie do nas były one kierowane. Kapitał kulturowy tych, którzy mieli być

62 J. Maj, Biblioteki publiczne na tle innych instytucji kultury, Warszawa 1996, s. 20-25, 123. 
ich czytelnikami wywodził się w znacznej części z doświadczeń przedwojennych. A te nie musiały być, przynajmniej w części dotyczącej spraw książki, dostępności kultury i oświaty, pozytywne. $Z$ tej m.in. przyczyny niektóre elementy komunistycznej ,papierowej rewolucji” (termin autorstwa Stanisława Kondka) nie budziły oporu. Bywało wprost przeciwnie: dekret o bibliotekach został powitany przez ówczesne autorytety bibliotekarskie z „optymizmem i entuzjazmem, graniczącym niekiedy z euforią" ${ }^{63}$, gdyż wprowadzał po raz pierwszy pojęcie ogólnokrajowej sieci bibliotek utrzymywanych przez państwo lub inne związki publiczno-prawne w celu ,prowadzenia w społeczeństwie jednolitej działalności kulturalnej za pomocą książki i bibliotek oraz umożliwienia każdemu obywatelowi korzystania ze zbiorów bibliotecznych całego kraju" ${ }^{64}$. Pierwsze lata powojenne są uznawane za bardzo korzystne dla prawodawstwa bibliotecznego ${ }^{65}$. Nie można również wykluczyć, że odchodzenie od rozwiązań rynkowych w kierunku państwowego centralnego planowania mogło wzbudzać wiele nadziei - nie tylko u rządzących, ale i u części rządzonych.

Bez wątpienia reinterpretacja tradycji Drugiej Rzeczpospolitej była ważnym elementem ideologizacji polityki wobec książki w Polsce w latach 19451956. Jak próbowałem zasygnalizować, odtworzenie głównych elementów dyskursu na ten temat otwiera nowe pytania badawcze o dużo większym ciężarze gatunkowym. Chodzi o recepcję owej reinterpretacji i - szerzej o rolę doświadczenia dwudziestolecia międzywojennego w życiu pierwszego pokolenia powojennego. Stulecie odzyskania niepodległości może być dobrą okazją do zmierzenia się z tym problemem. Oby jednak ciężar gatunkowy rocznicy nie skłaniał do wybielania realiów tego okresu. Bo oczernianie chyba już mamy za sobą...

\section{Bibliografia}

Archiwalia:

Archiwum Akt Nowych

Centralny Urząd Wydawnictw, Przemysłu Graficznego o Księgarstwa, sygn. 73, 84.

Komitet Centralny Polskiej Zjednoczonej Partii Robotniczej, sygn. 237/XVII-229, 237/XVIII-14.

Ministerstwo Kultury i Sztuki, Centralny Zarząd Bibliotek, sygn. 23, 49.

Związek Księgarzy Polskich, sygn. 6.

63 Tamże, s. 19.

64 T. Zarzębski, Polskie prawo biblioteczne 1773-1990, Warszawa 1991, s. 33.

65 L. Biliński, Biblioteki publiczne końca XX wieku, Warszawa 2001, s. 18. 
Opracowania, publikowane źródła:

Augustyniak J., Czytelnicy przedwojenni i dzisiejsi, „Książka i Kultura” 1945, nr 4-6, s. 2-3.

Bieńkowski W., O pseudo-nauce bibliologii i o najpilniejszych zadaniach bibliografii, Warszawa 1953.

Biliński L., Biblioteki publiczne końca XX wieku, Warszawa 2001.

Bromberg A., Książka w Polsce odrodzonej, „Przegląd Księgarski” 1948, nr 3, s. 34-35.

Daszkowski Z., O wspótpracę bibliotek naukowych z siecia bibliotek powszechnych (po konferencji w Jarocinie), „Przegląd Biblioteczny” 1954, z. 2, s. 120-125.

Dekret o bibliotekach, „Biuletyn Księgarstwa Spółdzielczego” 1946, nr 5, s. 2-4.

Dembińska Z., Założenia ideowe „Czytelnika”, „Książka i Kultura” 1945, nr 1, s. 5-7.

Dembowska M., Przysposobienie czytelnicze młodzieży szkolnej, „Biuletyn Państwowego Instytutu Książki” 1948, nr 3, s. 1-16.

Denisew W.N., Organizacja bibliografii w ZSRR, thum. J. Gruszecka, Warszawa 1951, Biuletyn Instytutu Bibliograficznego, t. 3, nr 4.

Dziesięć lat Polski Ludowej. Poradnik bibliograficzny, Warszawa 1954.

Filipkowska-Szemplińska J., Zadania ZBiAP w Polsce Ludowej. Referat wygłoszony na Zjeździe Delegatów ZBiAP w Warszawie 7 IV 1949, „Bibliotekarz” 1949, nr 3-4, s. $38-42$.

Grodek A., Rola i zadania bibliotek naukowych $w$ budownictwie socjalizmu $w$ naszym kraju, „Przegląd Biblioteczny” 1951, z. 3-4: Pamiętnik Konferencji Krynickiej 3-15 II 1951, s. 224-238.

Grycz J., Krótki zarys historii książki i bibliotek, Warszawa 1954.

Iwańczak E., III Plenum KC PZPR a zadania Zwiąku Bibliotekarzy i Archiwistów Polskich, „Przegląd Biblioteczny” 1950, z. 2, s. 98-104.

Janiczek J., Sprawy biblioteczne w ramach działalności Ministerstwa Oświaty, „Bibliotekarz" 1946, nr 1-2, s. 1-13.

Kempka Z., Rola bibliotek w Planie 6-letnim, „Bibliotekarz” 1950, nr 3-4, s. 33-40.

Klimowicz A., W sprawie planu wydawniczego, „Biuletyn Księgarstwa Spółdzielczego” 1947, nr 7/8, s. 102-104.

Kobieta wczoraj i dziś. Poradnik bibliograficzny, Warszawa 1954.

Kondek S., Papierowa rewolucja. Oficjalny obieg ksiażek w Polsce w latach 1948-1955, Warszawa 1999.

Kondek S., Władza i wydawcy. Polityczne uwarunkowania produkcji książek $w$ Polsce w latach 1944-1949, Warszawa 1993.

Łuszpak A., Katalogi rzeczowe w stużbie ideologii (na przykładzie Biblioteki Uniwersyteckiej we Wrocławiu w latach pięćdziesiatych XX wieku), [w:] Nie po myśli władzy. Studia nad cenzura i zakresem wolności stowa na ziemiach polskich od wieku XIX do czasów współczesnych, pod red. D. Degen i M. Żyndy, Toruń 2012, s. 263-279.

Łuszpak A., Obraz katalogów rzeczowych na łamach polskich czasopism bibliotekarskich w okresie stalinowskim, ,Z Badań nad Książką i Księgozbiorami Historycznymi” 2016, t. 10, s. 295-316. 
Łysakowski A., Określenie bibliografii. Przedmiot, metody i zadania na tle nauki o książce, „Biuletyn Instytutu Bibliograficznego” 1950, t. 3, nr 2, s. 15-43.

Łysakowski A., Zagadnienie treści $i$ wartości książki w bibliografii, „Biuletyn Instytutu Bibliograficznego" 1953, nr 9, s. 197-233.

Maj J., Biblioteki publiczne na tle innych instytucji kultury, Warszawa 1996.

Malawski S., Książki na wieś, „Biuletyn Księgarstwa Spółdzielczego” 1947, nr 9, s. $120-121$.

Muszkowski J., Życie książki, wyd. 2 il. i rozsz., Kraków 1951.

Osiem lat Polski Ludowej. Poradnik bibliograficzny, Warszawa 1952.

Planowa akcja upowszechniania czytelnictwa, „Przegląd Księgarski” 1948, nr 5, s. 70.

Po ogólnokrajowej naradzie bibliotekarzy, „Przegląd Biblioteczny” 1952, z. 2-3, s. $115-127$.

Prace normalizacyjne w zakresie bibliotekarstwa (Karty katalogowe czasopism. Karty akcesyjne czasopism), Warszawa 1948, Biuletyn Państwowego Instytutu Książki, t. $1, \mathrm{nr} 7$.

Puchalski J., Prace Józefa Grycza nad organizacją bibliotekarstwa publicznego w latach 1945-1949. Cz. I, „Z Badań nad Książką i Księgozbiorami Historycznymi” 2011, t. 5, s. 53-88.

Puchalski J., Prace Józefa Grycza nad organizacją bibliotekarstwa publicznego w latach 1945-1949. Cz. II, „Z Badań nad Książką i Księgozbiorami Historycznymi” 2012, t. 6, s. 79-112.

Rodziewicz Z., Zagadnienie kadr bibliotekarskich na Ogólnokrajowej Naradzie Bibliotekarzy, „Poradnik Bibliotekarza” 1952, nr 8, s. 173-177.

Rulikowski M., Księgoznawstwo, przeszłość oraz stan obecny wiedzy o książce $i$ nowe w niej kierunki, Warszawa 1936.

Sadowska J., Bibliografia zalecajacca w Polsce, „Przegląd Biblioteczny” 2016, z. 2, s. $177-195$.

Sadowska J., Marksistowskie poglady Władysława Bieńkowskiego w teorii i praktyce bibliotecznej, [w:] Ksiażka zawsze obecna. Prace ofiarowane Profesorowi Krzysztofowi Migoniowi, Wrocław 2010.

Sprawy książki w prasie, „Biuletyn Księgarstwa Spółdzielczego” 1946, nr 4, s. 5-7.

Tobera M., Księgarstwo spółdzielcze i prywatne w okresie trójstopniowości polskiego rynku książki (1945-1950), „Przegląd Biblioteczny” 2014, nr 3, s. 329-363.

Tobera M., Władza i ksiegarze prywatni (1945-1950), [w:] Nie po myśli władzy. Studia nad cenzura i zakresem wolności słowa na ziemiach polskich od wieku XIX do czasów współczesnych, pod red. D. Degen i M. Żyndy, Toruń, 2012, s. 99-128.

Uchwała Rady Państwa w sprawie upowszechnienia ksiązki i czytelnictwa w Polsce, „Bibliotekarz” 1948, nr 3, s. 33-34.

Vrtel-Wierczyński S., Teoria bibliografii w zarysie, Wrocław 1951.

Wczoraj analfabeci - dziś petnowartościowi obywatele Polski Ludowej, „Słowo Ludu” 1951, nr 65. 
Wojciechowski K., Potrzeby czytelnictwa masowego, „Bibliotekarz” 1950, nr 5-6, s. 66-70.

Wolpe H., W sprawie naszego ruchu wydawniczego, „Praca Księgarska. Biuletyn Księgarstwa Spółdzielczego" 1948, nr 11, s. 197-198.

Z tego «rekordu» trzeba zrezygnować, „Kurier Szczeciński” 1951, nr 16.

Zadania bibliotekarzy, „Poradnik Bibliotekarza” 1952, nr 8, s. 169-172.

Zagadnienia czytelnictwa $w$ Polsce Ludowej. Ogólnopolska Narada Bibliotekarzy w Warszawie w dn. 29-30 maja 1952 r., [red. A. Radłowska], Warszawa 1952.

Zaremba J., Było i tak. Wspomnienia, Wrocław 1976.

Zarzębski T., Polskie prawo biblioteczne 1773-1990, Warszawa 1991.

Źródła analfabetyzmu w Polsce $i$ walka państwa ludowego z tym zaniedbaniem kulturalnym, [Warszawa 1949]. 